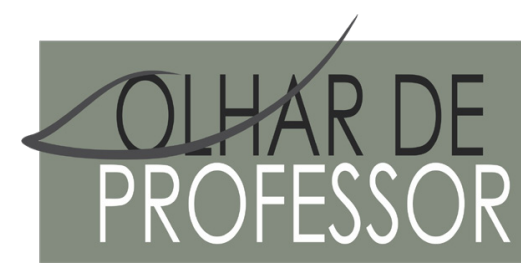

DOI: 10.5212/OLHARPROFR.v23.2020.15880.209209226254.0610

\title{
PRÁTICAS PEDAGÓGICAS ALTERNATIVAS EM UM CENÁRIO EXCEPCIONAL: ALGUNS PRESSUPOSTOS DAS EXPERIÊNCIAS DE EDUCAÇÃO A DISTÂNCIA NO URUGUAI
}

\author{
ALTERNATIVE PEDAGOGICAL PRACTICES IN AN EXCEPTIONAL SCENARIO: SOME ASSUMPTIONS OF \\ DISTANCE EDUCATION EXPERIENCES IN URUGUAY

\section{PRÁCTICAS PEDAGÓGICAS ALTERNATIVAS EN UN ESCENARIO DE EXCEPCIÓN: ALGUNOS SUPUESTOS DESDE EXPERIENCIAS DE EDUCACIÓN A DISTANCIA EN URUGUAY}

\author{
TANIA PRESA* \\ MARÍA EVANGELINA MÉNDEZ ${ }^{\text {** }}$ \\ NOELIA CAMPOS ${ }^{* * *}$
}

\begin{abstract}
Resumo: Este artigo aborda o estudo de práticas pedagógicas alternativas, presenciais, desenvolvidas no cenário de excepcionalidade devido à pandemia de COVID-19 no Uruguai. Um país que possui características particulares em termos de políticas de inclusão de tecnologia para escolas de todos os níveis há mais de dez anos. Compartilhamos uma reflexão pedagógica sobre certas suposições que denominamos mudanças da presencialidade para a virtualidade. Por fim, são apresentados alguns resultados do estudo de sistematização de experiências pedagógicas organizadas para análise nos seguintes eixos: meios e dispositivos utilizados, potencialidades e dificuldades de uso, atividades, acompanhamento de famílias, avaliação e teletrabalho professor.
\end{abstract}

Palavras-Chave: Práticas Pedagógicas. Alternativas. Movimentos Pedagógicos. Sistematização de Experiências.

\begin{abstract}
This article addresses the study of alternative pedagogical practices to face-to-face that have been developed in the scenario of exceptionality due to the COVID-19 pandemic in Uruguay. A country that has particular characteristics in terms of technology inclusion policies for schools at all levels for more than ten years. We share a pedagogical reflection on certain assumptions that we have called shifts from presentiality to virtuality. Finally, some results of the study of systematization of pedagogical experiences that were organized for analysis are presented in the following axes: means and devices used, potentialities and difficulties of use, activities, accompaniment of families, evaluation and teleworking teacher
\end{abstract}

Keywords: Alternative Pedagogical. Practices. Pedagogical movements. Systematization of experiences.

Resumen: El presente artículo aborda el estudio de prácticas pedagógicas alternativas a la presencialidad que se han desarrollado en el escenario de excepcionalidad por la pandemia COVID-19 en Uruguay. Un país que tiene características particulares en cuanto a políticas de inclusión de tecnologías a los centros educativos en

\footnotetext{
* Maestra. Doctoranda en Psicología. Magíster en Psicología y Educación, Facultad de Psicología, UdelaR. Licenciada en C. de la educación. FHUCE. UdelaR. Docente en Instituto Normal, Departamento de Informática y Primera Infancia. Consejo de Formación en Educación, Uruguay. (lic_taniapresa@hotmail.com)

${ }^{* *}$ Maestra. Licenciada en C. de la educación. FHUCE. UdelaR. Magister en Tecnología Educativa. Docente en Institutos Normales, Departamento Filosófico-Histórico-Pedagógico. Docente Orientador en Tecnologías, Unidad Académica de Tecnología Educativa. Consejo de Formación en Educación, Uruguay. (pedagogias2020@gmail.com)

*** Maestra. Magíster en Tecnología Educativa. Especialista en Entornos Virtuales de Aprendizaje. Docente Articulador en la Unidad Académica de Tecnología Educativa. Docente de Pedagogía e Investigación Educativa del Consejo de Formación en Educación, Uruguay. (noe738camp@gmail.com)
} 
todos los niveles desde hace más de diez años. Compartimos una reflexión pedagógica sobre ciertos supuestos que hemos denominado desplazamientos de la presencialidad a la virtualidad. Finalmente se presentan de forma sucinta algunos resultados del estudio de sistematización de experiencias pedagógicas que se organizaron para su análisis, en los siguientes ejes: medios y dispositivos utilizados, potencialidades y dificultades de uso, actividades, acompañamiento de las familias, la evaluación y el teletrabajo docente.

Palabras-clave: Prácticas Pedagógicas. Alternativas. Desplazamientos pedagógico. Sistematización de experiencias.

\section{INTRODUCCIÓN}

La pandemia y la cuarentena revelan que hay alternativas posibles, que las sociedades se adaptan a nuevas formas de vida cuando es necesario y se trata del bien común. Esta situación es propicia para pensar en alternativas a las formas de vivir, producir, consumir y convivir en los primeros años del siglo XXI. En ausencia de tales alternativas, no será posible prevenir la irrupción de nuevas pandemias (...)

Boaventura de Sousa Santos, 2020

\section{INTRODUCTION}

The pandemic and quarantine reveal that there are so much alternatives, societies adapt to new lifestyle when the common good is necessary. This situation is conducive to thinking about alternatives in order for living, producing, consuming and living together when 21st century was started. In the absence of such alternatives, it will not be possible to prevent the emergence of new pandemics (...)

Boaventura de Sousa Santos, 2020

This article is part of the line of work of a research team, which from 2016 with funding from the ANII (National Research Agency of Uruguay), began to inquire about alternative pedagogical practices in the school environment.

The purpose was to systematize experiences that show other ways of teaching and learning with political and ethical commitment that contributes to social justice, as a dialectical movement between the subject and the social project that it co-constructs (GÓMEZ SOLLANO, CORENSTEIN, 2013). In the current scenario, the objective has been the systematization and reflection around teaching and learning experiences that can be conceived as alternative pedagogical practices in an exceptional scenario: the pandemic.

On March 13, the coronavirus health emergency was announced in our country, after the confirmation of four cases. The first step was closed educational centers. This situation force to change from face-to-face education to distance education. It should be noted that this situation has a special feature in our territory: the Ceibal Plan.

This educational connectivity project, was began with a clear objective of social equity, it is installed in context of pandemic as a guarantee and organization of the logistics of distance education that Uruguayan educators previously had. Among the advances that the Ceibal Plan had, is the CREA educational platform (Contents and Resources for Education and Learning), becoming the space par excellence for virtual communication in the educational community. This platform is available for all educational levels in Uruguay, from initial education to tertiary education, even with access to private education centers, being put into practice in 2012.

After not attending the educational institutions, the education authorities have suggested to the educators, to continue the educational practices through the CREA platform fundamentally and the use of other resources that the educators consider pertinent. Faced with this current scenario, which transcends our country, virtual education has been installed as a great effort by all agents of education. 
From the students who must get used to using WhatsApp, cell phones and educational platforms, among other resources to learn and do the assigned tasks, families must generate new digital skills and accompany their children more than ever in their learning and educators generating new pedagogical strategies integrating digital technologies. Faced with this scenario of uncertainty, the educational community has appropriated these new ways of doing school.

\section{PEDAGOGICAL DISPLACEMENTS}

It has been this context that has allowed us to carry out a pedagogical reflection, from which to propose certain assumptions for analysis, which we have called pedagogical shifts from face-to-face to virtuality. These assumptions, understood as movements, itineraries, words that evoke turns and reveal ideas that have to do with: the ways of conceiving distance education, the social inequalities that are attenuated, the role of families in accompanying their children with school assignments, assessment, the place of teaching content and activities that educators propose, among others.

We understand that the current situation has prompted us to develop a pedagogy under construction, which is built around an emerging, diffuse episteme that does not cease to consolidate, to take hold. It is an intermittent and insecure, but not silent, pedagogy, made up of a kind of movement led by professionals from all over the educational system who have spread their proposals and ideas on various social networks. This solidarity movement of educators has disclosed certain practices, although perplexed, timid, they constitute the foundations of a pedagogy under construction, that of alternatives to teach in environments that, although known (virtual), have become strange. This has led us to reflect on the way of conceiving distance education, with its own characteristics, its advantages and disadvantages compared to face-to-face.

This situation has revealed two highly relevant assumptions: on the one hand, the difficulty of adapting the teaching proposals aimed at children who make up the smallest levels of the educational system and, on the other hand, has been highlighted by part of the Teaching collective with a greater awareness of the potential of virtuality and the irreplaceable nature of the educational relationship.

On the other hand, we made reference to the so-called shift towards greater social inequality, an aspect that moves and challenges us. Beyond the guarantee that the Ceibal Plan has given us in advance, beyond the achievements made regarding a smaller digital divide, situations of difficulty in connectivity and access to devices still persist. Added to this type of inequalities are those related to poverty, the digital skills that families have to accompany their children, the spaces and upbringing times dedicated to school tasks, among others. This displacement brings us closer to thinking about another of the assumptions that is closely related to the previous one, we refer to the role of family accompaniment. At this point, it is about thinking about the role of families, as allies, assistants and companions of school proposals, but not from a school function, but from an educability function.

In this sense, educators must promote the conditions of educability, proposing topics for working with the family, enabling their voices and being attentive, present to the difficulties that may be arising.

When we propose to attend conditions of educability, this implies also thinking about the place of evaluation in virtual environments, which presents itself as a great challenge. In the classroom, the evaluation is usually carried out through orality, in the various participations of the students, in the questions they ask, and in the various activities proposed in their notebook or books, but when one thinks of virtuality, in Occasionally, it becomes a waterfall of activities that serve as "evidence" of student learning. Therefore, evaluation should be considered as a long-term process, with proposals that involve putting at stake the knowledge addressed to solve a problem or the generation of a product in itself and that transcends the merely instrumental of the determined knowledge.

Likewise, in the current context, the particularities of each of our students should be taken into account in terms of their possibilities of access and sociocultural support in their immediate context. That is, today more than ever educational inequalities are generated that must be taken into account when planning the evaluation. This aspect becomes in relation to the contents that teachers prioritize today to be addressed in virtuality. 
One of the risks is trying to move the programmatic contents to the virtual environment. In this attempt, some characteristics or aspects of teaching are lost due to content that is not possible or similar with distance learning in this state of exception. In this sense, it is convenient, from the didactic planning, to pause in the weighting of curricular contents, which does not mean that they are not addressed, but are integrated into a teaching of knowledge that humanizes, that are conceived as "socially productive" (PUIGGRÓS, 1994).

This reflection around the assumptions or pedagogical displacements that we have overturned from the current scenario, we have tried to materialize them in a series of twenty principles that we have called "Manifest for a distance school education", that although we do not have the extension for in this article to disseminate them, we can say that the spirit of the principles that make it up propose to think pedagogical alternatives mediated by screens, where the focus is on linking and developing skills and competencies for the 21st century, considering the potential and limitations of virtuality.

\section{ON THE SYSTEMATIZATION OF EXPERIENCES}

The challenge when developing a systematization of experiences lies in articulating the action with the theory, in being able to justify what is done, combining the methodological value with the epistemic. In this sense, it is that we understand the systematization of experiences as a political-pedagogical process from which to give voice to its protagonists and thus be able to:

(...) build a knowledge about the different forms that practical thought assumes; on the different ways of knowing and approaching social reality, explaining the multiple speeches, readings and views of the problem on which it is necessary to extract learning and produce knowledge (BERRUTI, 2013, p.25).

The objective of this systematization is to interpret and analyze some experiences that educators in our country have been developing in times of pandemic in our country, at different educational levels. The data collection instruments applied up to now were questionnaires and narration of pedagogical experiences in written format by teachers. We plan to apply an in-depth interview in selected cases in later stages.

The first stage consisted of making available to educators a web form to collect certain data from the pedagogical experiences that make it possible to systematize it. At the time of writing this article, we have a systematization of a total of 29 experiences that were organized for analysis, in the following areas: resources and devices used, potentialities and difficulties of use, activities (attendance, hierarchy of areas), accompaniment of families, evaluation and teacher teleworking.

Regarding the institutional levels of membership, we find that 13\% belong to Initial Education, $74 \%$ to Primary Education, 4\% to the First Cycle of Secondary Education and 9\% Second Cycle of Secondary Education. The following graph shows the rate in which we have collected experiences.

FIGURE 1: GRADES IN WHICH TEACHERS WHO SHARE THEIR PEDAGOGICAL PRACTICES PERFORM, २०२०.

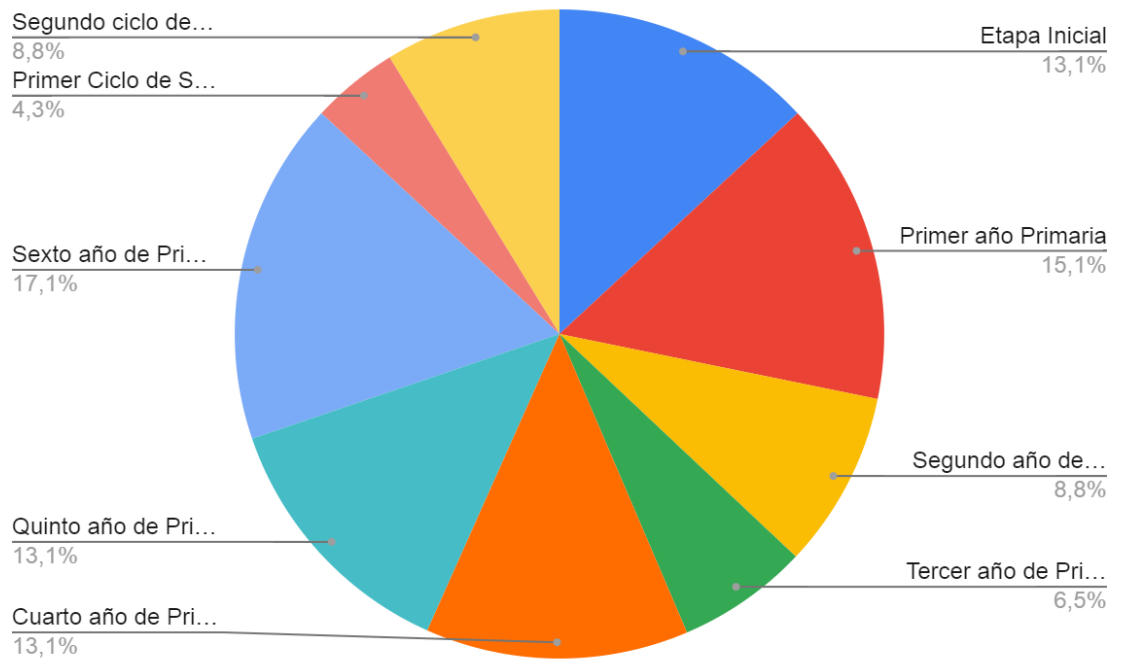

SOURCE: SELF MADE 
Regarding the means that have been used, teachers have combined the use of several of them as shown in the following graph; The following prevail: $86 \%$ use educational platforms, $79 \%$ use WhatsApp groups, $57 \%$ have used video calls.

\section{FIGURE 2: MEANS USED BY TEACHERS DURRING NON-ATTENDANCE, 2020.}

¿Qué medios utilizas para desarrollar prácticas de enseñanza y aprendizaje?

28 respuestas

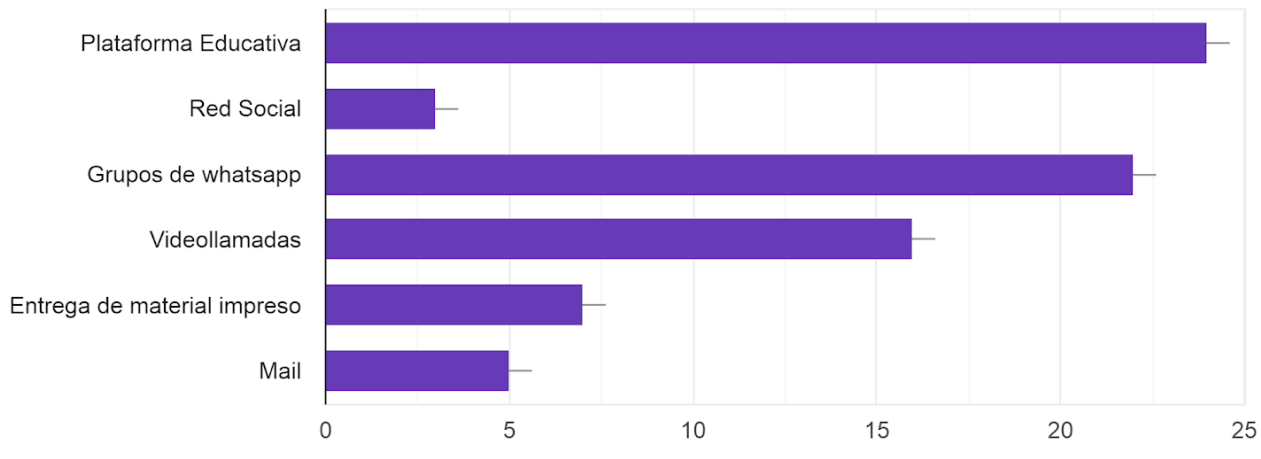

SOURCE: SELF MADE

Regarding the use of devices by students, they use more than one but the one that is notoriously prevalent is the cell phone, $85.7 \%$ of students have followed the course via cell phone. The second most used device is the class notebook with $61 \%$ of students who do it this way and third is the use of the laptop provided by Plan Ceibal with $46.4 \%$ use.

FIGURE 3: USE OF DEVICES BY STUDENTS DURING THE ABSENCE OF CLASSES, २०२०

¿Qué dispositivos utilizan tus alumnos para la realización de las propuestas?

28 respuestas

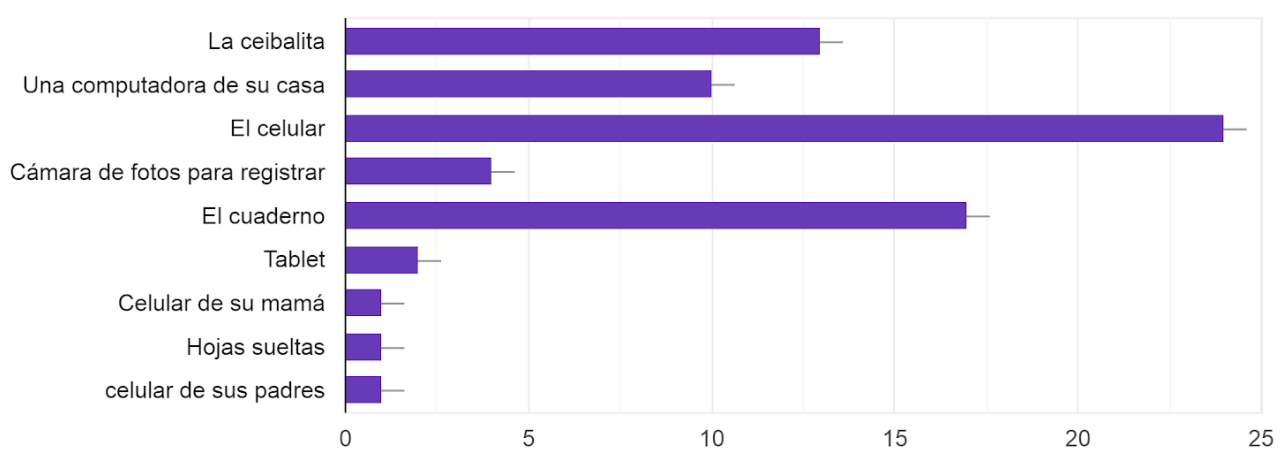

SOURCE: SELF MADE

Regarding the number of weekly activities that are proposed to students, a large majority (67.9\%) propose 1 to 5 activities, followed by 25\% of teachers who propose between 6 and 10 weekly activities.

The areas that are widely prioritized over others are Language and Mathematics, being in third place the approach of the artistic area. The justification for this hierarchy, in the cases that are not teachers of the (secondary) area, is that they are considered instrumental areas, because they are transversal disciplines, because they are fundamental to incorporate other content from other areas. Regarding the accompaniment of families:

a) $30 \%$ of the teachers express that they have been very present in the accompaniment.

b) $20 \%$ of teachers express that it is very varied. In the same group there are very accompanied children and others who have not followed the proposals. 
c) $20 \%$ of teachers state that families have not accompanied them in the process.

d) $15 \%$ of teachers express that they have shown interest and have accompanied.

e) $15 \%$ of teachers express that they have accompanied but with many difficulties of a formative nature and digital skills.

In relation to the evaluation, half of the teachers express that it is not a favorable moment to evaluate, almost the other half suggest that the evaluation should be formative or self-evaluation and co-evaluation modalities, as well as assessing the participation and commitment of the families. Only $5 \%$ state that even in this context it is important to maintain evaluative learning activities.

Regarding teaching telework, we gather data regarding: potentialities of mediating processes by technology, difficulties of mediating processes by technology, main difficulties in changing the modality from face-to-face to telework, emotional state of teaching during non-attendance.

\section{SOME ASSUMPTIONS FOR DISCUSSION}

The main potential of screen mediation was given in the possibility of continuing the link between educational institution-families-students, the diversity of educational resources found on the web and the possibility of using other resources that are not used in person. Undoubtedly, having previously an educational platform already developed led to great advantages over the shift from face-to-face to virtuality. The main difficulties in screen-mediated teaching are related to the lack of connectivity in homes and the lack of digital skills and instruction of families to accompany the training processes.

On the other hand, $45 \%$ of the teachers stated that the change from the face-to-face modality to telework implied a considerable increase in the hours of daily dedication. Another of the difficulties that concerns $20 \%$ of teachers is the difficulty in maintaining communication between families and children with the educational institution.

Finally, it seemed very important to us to relieve the emotional state of the teachers during the development of telework. In this sense, $25 \%$ show good emotional health, highlighting that they were able to adapt to this modality without great difficulties. The remaining $75 \%$ state that they have gone through the following emotional states: anxiety, tiredness, stress, overuse, depression, contempt, fright. Undoubtedly, these aspects will require further analysis, allowing us to delve into the consequences of teaching work in the current scenario and in projections for a post-pandemic pedagogy.

\section{REFERENCIAS}

BERRUTI, M., DABEZIES, M.J. Sistematización de experiencias de extensión. Cuadernos de Extensión N³. Extensión Universitaria: Montevideo, 2013. Disponible en: http://www.extension. udelar.edu.uy/cuadernos-de-extension/

DE SOUSA SANTOS, B. La cruel pedagogía del virus. CLACSO: Buenos Aires, 2020. Disponible en: https://mega.nz/file/7gxFhQJR\#Q4rAehS4TDHvGm15zLi-F178JmdFP8nEgk-weMpLjis

GÓMEZ SOLLANO, M. CORENSTEIN, M. Saberes, sujetos y alternativas pedagógicas. Contexto, conceptos y experiencias. UNAM: México, 2013. Disponible en: file://C:/Users/ Administrador/Downloads/Libro\%20Saberes\%20Versi\%C3\%B3n\%20Final\%20Visto\%20Bueno\%20 octubre\%202017.pdf

PUIGGRÓS, A. GÓMEZ SOLLANO, M. Alternativas pedagógicas, sujetos y prospectiva en la educación latinoamericana. Miño y Davila: Buenos Aires, 1994. 